\title{
PELATIHAN STRATEGI BELAJAR BAHASA INGGRIS SISWA KELAS III SMP WALISONGO DALAM MENGHADAPI UJIAN NASIONAL 2018
}

\author{
Maliqul Hafis ${ }^{1}$, Sahrawi², M.Iqbal Ripo Putra ${ }^{3}$, Tri Kurniawati ${ }^{4}$ \\ ${ }^{1234}$ Program Studi Pendidikan Bahasa Inggris \\ Fakultas Pendidikan Bahasa dan Seni IKIP PGRI Pontianak \\ e-mail: maliqulwiya@gmail.com ${ }^{1}$
}

\begin{abstract}
Abstrak
Pelatihan strategi belajar bahasa inggris bagi peserta didik yang akan menghadapi Ujian Nasional di SMP Walisongo memiliki Beberapa tujuan yaitu; 1) siswa memiliki pengetahuan tentang cara belajar bahasa inggris yang efektif dalam meningkatkan kemampuan mereka menghadapi ujian nasional; 2) siswa memiliki ketertarikan mempelajari bahasa inggris secara lebih antusias. Pengumpulan data dilakukan dengan menggunakan catatan Lapangan yang dilakukan dengan mendokumentasikan proses pembelajaran baik dari aktivitas guru maupun siswa serta lingkungan atau kondisi pembelajaran. Hasil dari analisa data menunjukkan bahwa 1) siswa mempunyai wawasan yang luas tentang cara belajar dan strategi menyelesaikan soal Ujian Nasional; 2) Terdapat perubahan sikap dari yang kurang aktif, tidak antusias dan kurang terlibat menjadi lebih aktif, antusias dan mau berinteraksi secara kolaborasi selama Pengajaran berlangsung.
\end{abstract}

Key Words: Strategi Belajar, Bahasa Inggris, Ujian Nasional

\begin{abstract}
English learning strategy training for the students who will face the National Examination at SMP Walisongo has several objectives, namely; 1) students have knowledge of how to learn English which is effective in improving their ability to face national examinations; 2) students have an interest in learning English more enthusiastically. Data collection is done by using Field notes conducted by documenting the learning process both from the activities of the teacher and students as well as the environment or learning conditions. The results of data analysis show that 1) students have extensive insights on how to learn and strategies to solve National Examination questions; 2) There is a change in attitude from those who are less active, not enthusiastic and less involved to become more active, enthusiastic and willing to interact collaboratively during the Teaching.
\end{abstract}

Key Words: learning strategies, English language, National examination.

\section{PENDAHULUAN}

Perkembangan ilmu pengetahuan dan teknologi saat ini berjalan dengan sangat cepat. Pengaruh dari perkembangan IPTEK ini telah dirasakan dalam berbagai bidang, seperti ekonomi, politik, sosial, budaya, pendidikan, dan sebagainya. Begitu luasnya perkembangan tersebut menuntut kesiapan kita sebagai warga negara Indonesia untuk mempersiapkan diri dalam menjawab 
berbagai tantangan di masa depan. Salah satu cara yang dapat ditempuh adalah melalui pengajaran bahasa inggris yang efektif agar peserta didik memiliki kemampuan bahasa inggris yang baik. Pendidikan yang berkualitas akan menghasilkan sumber daya manusia yang berkualitas dan berdaya saing agar dapat bertahan dalam kompetisi global.

Kemampuan berbahasa Inggris sangat diperlukan hampir semua jenjang pendidikan. Hal ini dikarenakan peranan bahasa inggris dimata dunia, dimana bahasa inggris menjadi salah satu bahasa international. Dengan kata lain, seseorang akan dengan sangat mudah berkomunikasi dengan masyarakat global apabila memiliki kemampuan bahasa inggris yang baik. Bahkan seringkali, bahasa inggris juga dijadikan sebagai salah satu persyaratan. Seorang guru harus dapat memastikan bahwa peserta didiknya dapat mengikuti pelajaran secara efektif dan mereka mampu mencapai standar yang ditetapkan dari masing-masing mata pelajaran. Guru harus mampu menfasilitasi para peserta didik selama proses belajar mengajar agar tujuan pendidikan bisa tercapai.

Salah satu komponen yang ada pada system pendidikan nasional tersebut adalah evaluasi. Proses membuat keputusan berdasarkan penilaian yang telah dilakukan adalah pengertian evaluasi, contohnya dalam bidang pendidikan. Dalam pendidikan, kegiatan evaluasi dapat dilakukan oleh guru, administrator pendidikan, atau siapaun yang mempunyai komitmen untuk memajukan dunia pendidikan. Kegiatan evaluasi harus dilakukan berdasarkan prinsip-prinsip dan prosedur evaluasi yang benar. Dengan melakukan sistem evaluasi yang baik diharapkan kualitas pendidikan akan meningkat.

Evaluasi hasil belajar dilakukan untuk mengetahui tingkat pencapaian prestasi belajar siswa setelah mengikuti kegiatan pembelajaran. Tujuan yang hendak dicapai melalui kegiatan belajar mengajar dirumuskan sebagai tujuan pembelajaran khusus. Menurut Suharsimi Arikunto (2002:25) terdapat dua alat evaluasi yang dapat digunakan untuk evaluasi, yaitu teknik non tes dan teknik tes. Penggunaan teknik evaluasi ini harus sesuai dengan apa yang akan diukur. Jika dibandingkan dengan teknik nontes, teknik tes bersifat lebih resmi karena penuh 
dengan batasan-batasan. Salah satu contoh bentuk evaluasi dengan teknik tes adalah ujian nasional (UN).

Beberapa catatan tentang perjalanan sejarah UN di mulai pada masa ORBA. Diamana sistem ujian nasional bermula saat orde baru di bawah kroni Soeharto dan telah mengalami beberapa kali perubahan dari tahun ke tahun, perkembangan ujian nasional tersebut yaitu: Periode tahun 1965 - 1971, pada periode ini, sistem ujian akhir yang diterapkan disebut dengan Ujian Negara, berlaku untuk semua mata pelajaran. Bahkan ujian dan pelaksanaannya ditetapkan oleh pemerintah pusat dan seragam untuk seluruh wilayah di Indonesia.

Periode 1972 - 1982, sistem Ujian Sekolah pelaksanaan diselenggarakan oleh masing-masing. Pemerintah pusat hanya menyusun dan mengeluarkan pedoman yang bersifat umum. Untuk meningkatkan dan mengendalikan mutu pendidikan serta diperolehnya nilai yang memiliki makna yang "sama" dan dapat dibandingkan antar sekolah.

Periode 1982 - 2002, pada tahun 1982 dilaksanakan ujian akhir nasional yang dikenal dengan sebutan Evaluasi Belajar Tahap Akhir Nasional (EBTANAS). Dalam EBTANAS dikembangkan dan diseragamkan seluruh sekolah di Indonesia. Periode 2002-2004, sistem EBTANAS diganti dengan penilaian hasil belajar secara nasional dan kemudian berubah nama menjadi Ujian Akhir Nasional (UAN). Perbedaan yang menonjol antara UAN dengan EBTANAS adalah dalam cara menentukan kelulusan siswa, terutama sejak tahun 2003. Untuk kelulusan siswa pada UAN ditentukan oleh nilai mata pelajaran secara individual. Penentuan lulus di tentukan oleh hasil siswa pada UAN.

Periode 2005 - sekarang, mulai tahun 2005 untuk mendorong tercapainya target wajib belajar pendidikan yang bermutu, pemerintah menyelenggarakan Ujian Nasional (UN) untuk SMP/ MTs/ SMPLB dan SMA/ SMK/ MA/ SMALB/ SMKLB. Sedangkan untuk mendorong tercapainya target wajib belajar pendidikan yang bermutu, mulai tahun ajaran 2008/2009 pemerintah menyelenggarakan Ujian Akhir Sekolah Berstandar Nasional (UASBN) untuk $\mathrm{SD} / \mathrm{MI} / \mathrm{SDLB}$. 
Segala metamorfosis Ujian Nasional yang dilakukan oleh pemerintah hanyalah remeh -temeh kurikulum, seolah-olah pemerintah peduli terhadap kualitas pendidikan. Nampak jelas bahwa Ujian Nasional peninggalan rezim Orde Baru adalah upaya untuk menyeragamkan kualitas pendidikan di Indonesia yang nyata-nyatanya berbeda. Bagaimana mungkin melakukan penilaian terhadap kemajuan kualitas pendidikan dengan persentase kelulusan pertahun siswa? Padahal fakta-fakta di atas telah menunjukan bahwa UN hanya ajang kongkalingkong yang tidak ada hubungannya dengan kemajuan kualitas pendidikan. Gonta-ganti "Ujian Nasional” hingga kurikulum hanya berganti baju saja dan membuang sia- sia anggaran pendidikan tanpa menyelesaikan masalah yang paling fundamental dari sistem pendidikan Indonesia. Dunia pendidikan di Indonesia akan terus terpuruk dan jatuh dalam jurang kehancuran. Arena sekolah seharusnya menjadi ajang kegembiraan siswa mengasah pengetahuan, meningkatkan kreatifitas demi meningkat mutu pendidikan yang berkualitas serta memiliki solidaritas tinggi untuk menyelesaikan realitas.

UN merupakan penilaian pada akhir proses pembelajaran di sekolah. Penilaian merupakan serangakaian kegiatan untuk memperoleh, menganalisis,dan menafsirkan data tentang proses dan hasil belajar siswa yang dilakukan secara sistematis dan berkesinambungan sehingga menjadi informasi yang bermakna dalam mengambil keputusan. Penilaian pada akhir proses pembelajaran dilakukan dalam bentuk ujian untuk mendapatkan data dan informasi obyektif sebagai hasil pengukuran.

Pemerintah telah mengambil kebijakan untuk menerapkan UN sebagai salah satu bentuk evaluasi pendidikan. Menurut Keputusan Menteri Pendidikan Nasional No.153/ U/ 2003 tentang UN tahun pelajaran 2003/2004 disebutkan bahwa tujuan UN adalah untuk mengukur pencapaian hasil belajar peserta didik melalui pemberian tes pada siswa SLTP dan siswa SLTA. Selain itu, UN bertujuan untuk mengukur mutu pendidikan dan mempertanggungjawabkan penyelenggaraan pendidikan di tingkat nasional, provinsi, kabupaten, sampai tingkat sekolah. UN berfungsi sebagai alat pengendalian mutu pendidikan secara nasional, pendorong peningkatan mutu pendidikan secara nasional, bahan dalam 
menentukan kelulusan peserta didik, dan sebagai bahan pertimbangan dalam seleksi penerimaan pada jenjang pendidikan yang lebih tinggi. UN merupakan salah satu bentuk evaluasi belajar pada akhir tahun pelajaran yang diterapkan pada beberapa mata pelajaran yang dianggap "penting”. Ujian nasional adalah salah satu jenis evaluasi yang dilakukan pada dunia pendidikan dan disesuaikan dengan standar pencapaian hasil secara nasional.

Hasil ujian di suatu sekolah akan memberikan informasi tingkat keberhasilan pencapaian siswa dari tujuan pembelajaran atau intruksional. Tingkat keberhasilan ini akan mengambarkan kemampuansiswa yang sebenarnya. Hasil ujian tersebut dapat digunakan sebagai dasar penyempurnaan program pembelajaran. Dengan demikian hasil ujian akan bermanfaat sebagai bahan umpan balik dalam proses pembelajaran dan hasil ujian digunakan untuk mengetahui efektivitas dan tingkat pencapaian atau keberhasilan suatu program kegiatan terutama program pengajaran.

Tujuan UN adalah untuk mengukur pencapaian hasil belajar siswa; mengukur mutu pendidikan di tingkat nasional, provinsi, kabupaten atau kota, dan sekolah/madrasah; dan mempertanggungjawabkan penyelengga-raan pendidikan secara nasional, provinsi, kabupaten atau kota, dan sekolah/ madrasah, kepada masyarakat. Penyelenggaraan UN menjadi salah satu syarat penentuan kelulusan siswa pada jenjang SMP, SMA dan SMK selain tiga (3) syarat lainnya, yaitu: (1) menyelesaikan seluruh program pembelajaran, (2) memperoleh nilai sikap/perilaku minimal baik, dan (3) lulus USBN sesuai dengan kriteria yang ditetapkan oleh satuan pendidikan. (Permendikbud Nomor 4 Tahun 2018 tentang Penilaian Hasil Belajar oleh Satuan Pendidikan dan Penilaian Hasil Belajar oleh Pemerintah).

Penetapan nilai standar kelulusan tersebut ditentukan oleh Badan Standar Nasional Pendidikan (BSNP). Berdasarkan Prosedur Operasi Standar (POS) ujian nasional yang dikeluarkan oleh BSNP, peserta UN dinyatakan lulus UN jika memilki nilai rata-rata minimum yang telah ditentukan untuk seluruh mata pelajaran yang diujikan, dengan tidak ada nilai dibawah 4,00. (BSNP) 
Untuk Sekolah menengah pertama (SMP), mata pelajaran yang di ujikan pada UN adalah matematika, bahasa Indonesia, dan bahasa inggris. Setiap sekolah tentunya mempunyai tujuan yang ingin dicapai, begitupun dengan SMP Walisongo. SMP Walisongo ingin lulusan mereka dapat melanjutkan pendidikan ke jenjang perguruan yang lebih tinggi. Salah satu upaya yang dilakukan adalah dengan peningkatan prestasi belajar.

SMP Walisongo telah meluluskan banyak peserta didiknya, walaupun demikian, pihak SMP Walisongo masih memiliki kendalakendala seperti: bagaimana cara mengembangkan mental anak untuk menghadapi ujian, kurangnya pemahaman siswa tentang mata pelajaran bahasa inggris, kejenuhan yang dialami siswa ketika sedang belajar bahasa inggris, dan kendalakendala lainnya.

SMP Walisongo mempunyai harapan agar seluruh warga sekolah dapat memanfaatkan waktu dengan sebaik-baiknya, akan tetapi yang menjadi kendala adalah kurangnya waktu yang dimiliki guru dan siswa dalam pelaksanaan proses belajar mengajar, dan belum meratanya pemahaman siswa dalam mata pelajaran bahasa inggris. Nilai kriteria ketuntasan minimal untuk mata pelajaran bahasa di SMP Walisongo adalah 75.

Berdasarkan uraian diatas, maka peneliti tertarik untuk mencoba mengangkat permasalahan tersebut dengan judul "Pelatihan Strategi Belajar Bahasa Inggris Siswa Kelas III SMP Walisongo Dalam Menghadapi Ujian Nasional 2018.

\section{METODE}

Kegiatan ini merupakan sebuah kegiatan pengabdian kepada masyarakat (PKM) dimana tim dari program studi pendidikan bahasa inggris melakukan pengajaran terhadap siswa SMP Walisongo kelas III untuk membantu mereka meningkatkan motivasi dalam belajar khususnya mata pelajaran bahasa inggris. Dengan adanya kegiatan yang berupa pengajaran menggunakan games ini diharapkan siswa akan lebih merasa tertarik dan termotivasi untuk belajar kosa kata baru dalam bahasa inggris. Sehingga peserta didik menjadi lebih proses pembelajaran dapat berjalan secara lebih efektif. 
SMP Walisongo beralamat di Jl. Ampera, Sungai Bangkong, Pontianak Kota, Kota Pontianak, Kalimantan Barat. SMP Walisongo memiliki lokasi yang strategis karena barada di kota pontianak, dekat dengan keramaian yang di kelilingi oleh komplek perumahan dan pasar. Karenanya menjadi sangat penting untuk mengembangkan dan meningkatkan kualitas belajar siswa di sekolah tersebut.

Subjek penelitian ini adalah siswa kelas III SMP Walisongo pada tahun akademik 2017/2018. Jumlah seluruh siswa 22 orang yang terdiri dari 13 siswa laki-laki dan 9 siswa perempuan. Pengumpulan data yang dipakai dalam penelitian ini adalah catatan lapangan. Catatan Lapangan dilakukan dengan mendokumentasikan proses pembelajaran baik dari aktivitas guru maupun siswa serta lingkungan atau kondisi pembelajaran dan foto kegiatan selama proses belajar mengajar baik sebelum maupun ketika dilaksanakan tindakan. Adapun materi yang digunakan dalam PKM ini mencakup dua hal yaitu:

1. tentang contoh-contoh soal UNBK untuk Mata Pelajaran Bahasa Inggris Kegiatan pengenalan contoh-contoh soal UNBK untuk Mata Pelajaran Bahasa Inggris dilakukan secara offline menggunakan kertas dan pensil. Materi ini disediakan dalam kegiatan ini untuk melatih kemampuan siswa memahami contoh-contoh soal ujian Bahasa Inggris dan untuk melatih strategi siswa dalam penyelesaian soal ujian Bahasa Inggris. Materi contoh soal ujian yang digunakan memuat kisi - kisi dan contoh soal.

2. Materi tentang latihan soal-soal online yang dapat dilakukan siswa secara mandiri melalui jaringan komputer dan internet sendiri ataupun melalui smartphone. Pada kegiatan ini untuk memaksimalkan persiapan siswa, tim pemateri dosen juga memberikan informasi laman khusus yang menyediakan latihan online gratis bagi siswa dalam melatih keterampilan mereka dalam menyelesaian soal UNBK pada mata pelajaran Bahasa Inggris. Latihan online ini sangat penting dilakukan siswa mengingat soal Bahasa Inggris memuat soal Listening dalam bentuk audio sehingga siswa memerlukan latihan khusus terkait keterampilan ini. Latihan soal ini dapat siswa akses melalui laman https://www.tryoutunonline.com/. Berikut ini merupakan tampilan awal laman 
tersebut.

\section{SOAL UNBK dan USBN}

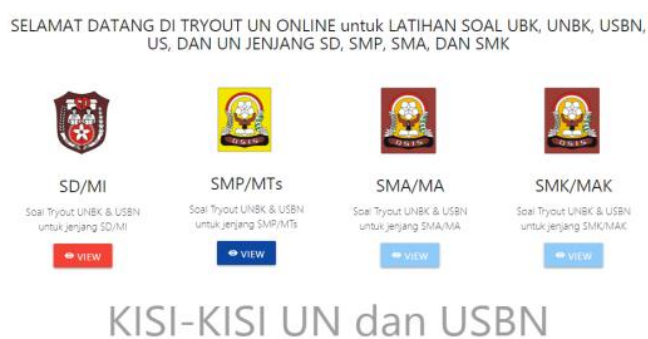

\section{HASIL DAN PEMBAHASAN}

Seorang guru harus dapat memastikan bahwa peserta didiknya dapat mengikuti pelajaran secara efektif dan mereka mampu mencapai standar yang ditetapkan dari masing-masing mata pelajaran. Guru harus mampu menfasilitasi para peserta didik selama proses belajar mengajar agar tujuan pendidikan bisa tercapai. Namun dalam proses pembelajaran sering juga terjadi hambatan yang harus ditangani secara baik oleh guru agar. Terdapat beberapa masalah yang dapat menghambat mereka untuk menguasai Bahasa Inggris. Masalah-masalah tersebut adalah:

1. Jarangnya guru berbicara dengan Bahasa Inggris di dalam kelas. Hal ini dirasakan sebagai penghambat siswa dalam meningkatkan bkemamp uan mereka karena mereka jadi tidak terbiasa mendengar orang lain berbahasa Inggris.

2. Pelajaran terlalu ditekankan pada tata bahasa (dan bukan pada percakapan), tetapi siswa jarang diberi arahan mengenai bagaimana dan apa fungsi dari unsur-unsur tata bahasa yang mereka pelajari tersebut.

3. Kosa kata yang diajarkan tidak terlalu berguna dalam percakapan sehari-hari. Materi tentang kata-kata yang diberikan oleh guru Bahasa Inggris di sekolah terlalu bersifat teknis, misalnya mengenai industrialisasi, reboisasi, dan lainlain, sementara siswa tetap saja mengalami kesulitan untuk mengartikan katakata yang banyak digunakan pada film, majalah, dan situs-situs internet berbahasa Inggris. Bahkan kadang-kadang, siswa sangat hapal istilah-istilah 
Bahasa Inggris untuk bidang politik (seperti misalnya reformation, globalization, dan lain-lain) tetapi tidak dapat menyebutkan benda-benda yang biasa mereka pakai sehari-hari dalam Bahasa Inggris (misalnya celengan, selokan, dan lain-lain). Kosa kata seperti yang dipelajari di sekolah tidak memungkinkan siswa dapat memulai percakapan dengan orang asing dengan menggunakan Bahasa Inggris.

4. Materi pelajaran Bahasa Inggris di SMP tidak berkesinambungan. Para siswa menyatakan bahwa sering terjadi pengulangan materi (seperti misalnya tenses) yang telah diajarkan di SMP di tingkatan SMU, tetapi tetap saja fungsi dan pengaplikasiannya dalam kehidupan sehari-hari kurang jelas.

Penelitian ini menggunakan teknik analisa data deskriptif kualitatif. Data yang diperoleh dari penelitian ini berupa data catatan lapangan yang dilakukan selama proses penelitian berlangsung dan nilai tes prestasi belajar yang dilakukan pada akhir kegiatan. Berdasarkan hasil analisis data dari alat pengumpulan data yaitu catatan lapangan. Berikut adalah peta kajian analisis data berdasarkan masingmasing target kegiatan.

\begin{tabular}{|c|c|}
\hline Target & Analisis data \\
\hline $\begin{array}{l}\text { 1. mempersiapkan } \\
\text { pengetahuan tentang cara } \\
\text { belajar bahasa inggris yang } \\
\text { efektif dalam } \\
\text { meningkatkan kemampuan } \\
\text { mereka menghadapi ujian } \\
\text { nasional pada mata } \\
\text { pelajaran Bahasa Inggris. }\end{array}$ & $\begin{array}{l}\text { Analisis data dilakukan berdasarkan isian pada } \\
\text { catatan lapangan yang dilengkapi dengan foto } \\
\text { kegiatan yang dilakukan } \quad \text { untuk } \\
\text { mendokumentasikan aktivitas proses } \\
\text { pendampingan serta lingkungan atau kondisi } \\
\text { pada saat kegiatan pengajaran berlangsung. }\end{array}$ \\
\hline $\begin{array}{l}\text { 2. Meningkatkan ketertarikan, } \\
\text { rasa percaya } \\
\text { diri, dan antusias siswa } \\
\text { dalam menyelesaikan soal } \\
\text { Ujian Nasional } \\
\text { Bahasa Inggris. }\end{array}$ & $\begin{array}{l}\text { Analisis data dilakukan berdasarkan jawaban } \\
\text { Tanya jawab siswa, guru dan/atau } \\
\text { kepala sekolah serta catatan lapangan setelah } \\
\text { diberikan gambaran } \\
\text { model pelaksanaan pengerjaan soal UN. }\end{array}$ \\
\hline
\end{tabular}

Hasil pengamatan pada catatan lapangan (field note) terhadap kegiatan siswa dalam mengerjakan soal tes UN mata pelajaran Bahasa Inggris pada lembar unjuk kerja menunjukan sikap yang semangat, bertanya pada saat diskusi penyelesaian contoh-contoh soal tes, bahkan ada juga yang menanyakan strategi penyelesaian soal untuk beberapa materi Bahasa Inggris yang tidak ada di dalam 
lembar unjuk kerja. Perubahan sikap yang diamati ini dapat disimpulkan sebagai adanya peningkatan keterampilan siswa dalam menyelesaikan soal Bahasa Inggris berbasis komputer.

Isian pada catatan lapangan yang dilengkapi dengan foto kegiatan yang dilakukan untuk mendokumentasikan aktivitas proses pendampingan serta lingkungan atau kondisi pada saat kegiatan pendampingan berlangsung menunjukan gejala yang positif dalam rangka mempersiapkan siswa dalam menghadapi Ujian Nasional (UN) tahun 2018 pada mata pelajaran Bahasa Inggris. Siswa bersikap sangat baik, antusias dan semngat selama kegiatan pendampingan. Mereka tidak menunjukan perilaku merasa terpaksa apalagi tertekan selama mengikuti kegiatan pendampingan. Beberapa siswa menunjukan sikap kepedulian mereka terhadap kegiatan yang berlangsung dengan mengajukan pertanyaanpertanyaan seputar isu UN dan mau dengan senang hati mengerjakan contohcontoh soal UN baik melalui lembar unjuk kerja maupun melalui laman-laman simulasi tes yang diberikan.

\section{SIMPULAN}

1. Siswa menjadi lebih antusias, percaya diri dan termotivasi dalam menyelesaikan soal soal ujian Nasional. Selama proses pembelajaran juga, para siswa menunjukkan antusias yang sangat baik meskipun kegiatan ini hanya berlangsung dua hari, dampak yang dihasilkan terasa sangat efektif, siswa menjadi termotivasi belajar bahasa inggris.

2. Selama Proses pengajaran tentang strategi belajar bahasa inggris dalam menghadapi ujian nasional 2018. Siswa yang sudah berada dikelas tiga SMP mendapatkan informasi yang sangat berguna untuk dapat mengatur waktu belajar mereka menjadi lebih efektif. Para siswa juga dapat mempersiapkan diri sedini mungkin kemampuan bahasa inggris mereka dan siswa dapat belajar bahasa inggris secara lebih mudah sesuai dengan materi yang sudah disampaikan selama kegiatan berlangsung. Sehingga setiap kegiatan yang dilakukan oleh dosen dapat mencapai hasil yang maksimal dan para peserta didik dapat meningkatkan kesiapan mereka dalam menghadapi ujian. 


\section{DAFTAR PUSTAKA}

Arikunto, S. (2002). Dasar-dasar Evaluasi Pendidikan. Jakarta: Bumi Aksara.

Permendikbud Nomor 4 Tahun 2018 (2018). Penilaian Hasil Belajar oleh Satuan Pendidikan dan Penilaian Hasil Belajar oleh Pemerintah. Jakarta: Kementerian Pendidikan dan Kebudayaan.

Pusat Penilaian Pendidikan, Kementerian Pendidikan dan Kebudayaan Republik Indonesia.

Kemendikbud, 2013. Hasil Konvensi Ujian Nasional. Diambil pada tanggal 6 November 2016 darihttp://www.kemdiknas.go.id/kemdikbud/sites/default/ files/ Hasi1\%20 Konvensi \%20UN.pdf

Tim Penyusun. 2017. Buku Panduan Pelaksanaan Pengabdian kepada Masyarakat. Pontianak: Lembaga Pengabdian kepada Masyarakat IKIP PGRI Pontianak. 